\title{
Rhabdomyolysis after lamotrigine overdose: a case report and review of the literature
}

\author{
Sokratis E. Karaoulanis*', Markos Syngelakis and Konstantinos Fokas
}

\begin{abstract}
Background: Lamotrigine is an effective anticonvulsant drug that has also been demonstrated to be effective in the treatment of bipolar disorder. We report a case of rhabdomyolysis after intentional overdose in a woman aged 48.

Case presentation: A 48-year-old female presented to the emergency department after an acute ingestion of $6 \mathrm{~g}$ of lamotrigine. The patient suffered from bipolar disorder, and she was taking lamotrigine and olanzapine. At that point, she had a major depressive episode, and she wanted to commit suicide. Activated charcoal was administered in the emergency department. Her vital signs were still normal, and she entered the Medical clinic, where she had been there for 2 days in a good condition. The hematological and biochemical results were normal. On the fourth day, the levels of creatine phosphokinase (CPK) showed remarkable increase $(2500 \mathrm{IU} / \mathrm{ml})$. Fluid and bicarbonate intravenous administration was performed, and CPK levels returned to normal after 3 days.

Conclusion: The majority of patients exposed to lamotrigine in overdose experienced no toxic clinical effects. The most common clinical effects are drowsiness and lethargy, vomiting, nausea, ataxia, dizziness/vertigo, and tachycardia. In this case report, the patient was alert and did not have any serious complications, except for mild rhabdomyolysis, which was the main consequence of lamotrigine overdose.
\end{abstract}

Keywords: Lamotrigine, Overdose, Rhabdomyolysis

\section{Background}

Antiepileptic drugs are being used across a wider number of indications, including bipolar affective disorders and other psychiatric diseases. Carbamazepine, valproate, and lamotrigine have demonstrated efficacy in the treatment of acute mania and are capable of preventing relapse in patients with bipolar disorder. In view of all these factors, there has been more widespread use of antiepileptic drugs in patients with underlying psychiatric disorders, often as an unlicensed indication. This patient group is at substantially increased risk of self poisoning.

We present the case of mild rhabdomyolysis that was caused by lamotrigine overdose in a patient suffering from bipolar disorder.

*Correspondence: skar@med.uth.gr

First Psychiatric Department, Aristotle University of Thessaloniki, Thessaloníki, Greece

\section{Case presentation}

A 48-year-old female patient presented to the emergency department after an acute ingestion of 30 tablets of $200 \mathrm{mg}$ lamotrigine. The patient suffered from bipolar disorder, and she was also taking olanzapine and oxcarbazepine. Nevertheless, she admitted that she stopped taking her medication 2 months ago. She said that lamotrigine was the only drug that she had ingested. An empty box containing 30 lamotrigine pills was found next to her bed. The patient was alone when she swallowed the pills. Her daughter told us that her mother had been very sad for a period of 10 days because her son had died because of heroin overdose. Afterward, her mother told her that there was no reason for her to live and to continue taking her medication. Consequently, it seems more possible that the patient did not take any other medication. A toxicologic analysis would have been useful in this case, but unfortunately it was never done. 
There was no history of illicit drug use or alcoholism, apart from smoking.

The patient was alert and her blood pressure, pulse rate, and temperature were within normal limits. The neurologic examination disclosed no focal findings.

Gastric lavage with activated charcoal was administered. Hematological and biochemical examinations, including liver function tests, were normal. Her electrocardiogram did not reveal any abnormalities. Then, the patient was admitted to the Medical Clinic, in order to ensure the early detection of any side effects of the high dose of lamotrigine. She remained at the Medical Clinic for 2 days. On the third day, as long as she did not face any problem (the blood and biochemical studies were normal), she was transferred to the Psychiatric Clinic.

The biochemical studies which were carried out in the Psychiatric Clinic showed that the value of creatine phosphokinase (CPK) was $620 \mathrm{IU} / \mathrm{ml}$ (normal 24-204 IU/ml). The following day CPK levels reached $2500 \mathrm{IU} / \mathrm{ml}$.

Fluid and bicarbonate intravenous administration was performed, and 3 days later, CPK returned to normal levels.

She was depressed and wanted to commit suicide because of the death of her son. She was suffering from bipolar disorder but did not comply with her pharmacological treatment.

\section{Review of the literature}

The most common clinical effects arising from lamotrigine overdose are drowsiness and lethargy, vomiting, nausea, ataxia, nystagmus, dizziness/vertigo, and tachycardia. Major clinical effects, which are rare, include coma, seizures, respiratory depression, cardiovascular shock, and multi-organ systemic allergic-type reaction [1-11]. In all these case reports, lamotrigine was combined with other drugs. However, Moore et al. reported a case series of patients with lamotrigine only overdose, and they had found that the consequences were seizures, hypertension, tachycardia, tachypnea, altered mental status, myoclonus, and QRS prolongation [10]. In two cases, the patients died, but in one case, there was a multiple drug overdose (lamotrigine, ethanol, thioridazine, carbamazepine, and paroxetine) (Table 1) [11, 12].

The outcome of lamotrigine overdose depends on a variety of factors, like the age, sex, the medical disease, and the simultaneous ingestion of other medications. The age is very important for the clinical outcome of lamotrigine overdose. It seems that in children, the ingestion of high amount of lamotrigine causes generalized seizures [13-15]. In adults, seizures are reported [16], but not so often like in children.

Another important factor for the clinical picture of lamotrigine overdose is the disease of the patient who was taking lamotrigine. The majority of patients suffered from epilepsy. In these cases, lamotrigine, usually, caused seizures $[16,17]$. On the contrary, in patients with bipolar disorder, seizures might not be so frequent result [18, 19]. In one case report, a bipolar patient who co-ingested lamotrigine and ethanol developed epileptic seizures [20]. However, it is noteworthy that a bipolar patient presented with anticonvulsant hypersensitivity syndrome (including symptoms such as fever, rash, and hepatitis) after lamotrigine overdose [19].

The combination of lamotrigine with other medications must be taken into account in the cases of lamotrigine overdose. It is combined, usually, with other antiepileptic drugs, with antidepressant drugs and with antipsychotic drugs. In these cases, the level of consciousness is disturbed (reduced level of consciousness, stupor, coma, etc.) $[17,18,20-22]$, and cardiovascular collapse may be present [23] Concerning the sex, women are more likely to ingest large amounts of lamotrigine than men [24].

The patient, who was presented above, ingested $6 \mathrm{~g}$ of lamotrigine. This is one of the largest amounts of lamotrigine ingested alone, ever reported. This patient developed only mild rhabdomyolysis without any other clinical outcome. Mild rhabdomyolysis is also reported in another case report [20], in which the amount of lamotrigine was unknown and the patient presented with epileptic seizures. Consequently, the authors did not know whether rhabdomyolysis was primary or the result of seizures. In our case, rhabdomyolysis appeared without seizures. Therefore, it seems that mild rhabdomyolysis is the primary outcome of lamotrigine overdose.

In this case, the pathogenic mechanism of rhabdomyolysis is not clear. It could be hypothesized that the overdose of lamotrigine led to rhabdomyolysis due to a genetic predisposition. For example, it was found that patients with virally induced rhabdomyolysis had malignant hyperthermia susceptibility (MHS)-associated.

RYR1 mutations [25, 26]. Therefore, in our case maybe the combination of environmental and genetic factors caused rhabdomyolysis [27].

In general, the ingestion of $6 \mathrm{~g}$ of lamotrigine did not cause any serious clinical effect on our patient. This is an important factor for patients with bipolar disorder who are prone to suicidal ideation and commitment of suicide-because these patients might try to commit suicide by taking excessive amounts of medications which are given to them by doctors in order to treat their problem. In addition, lamotrigine protects bipolar patients from the influence of depressive episodes, which are the cause of suicidal ideation. Lithium is another agent used in bipolar disorder, which has proven to be an effective deterrent against the suicidal tendency of these patients. However, lithium has serious adverse effects which limit 
Table 1 Case reports involving lamotrigine overdose

\begin{tabular}{|c|c|c|c|c|c|}
\hline Case report & $\begin{array}{l}\text { Amount } \\
\text { of lamotrigine }\end{array}$ & Disease & Age & Other drugs & Clinical presentation \\
\hline$[16]$ & $4.1 \mathrm{~g}$ & Epilepsy & 42 year & - & Status epilepticus, ataxia, \\
\hline$[19]$ & $2.7 \mathrm{~g}$ & Bipolar disorder & 49 year & - & $\begin{array}{l}\text { Anticonvulsant hypersensitivity } \\
\text { syndrome }\end{array}$ \\
\hline$[5]$ & 1350 mg & Epilepsy & 26 year & - & Ataxia, nystagmus \\
\hline$[15]$ & $800 \mathrm{mg}$ & No disease & 2 year & - & Generalized seizures, ataxia \\
\hline$[13]$ & $43 \mathrm{mg} / \mathrm{kg}$ & & 2 year & - & Generalized seizures \\
\hline$[14]$ & Unknown & No disease & 19 month & - & Generalized seizures \\
\hline$[17]$ & $32 \mathrm{~g}$ & Epilepsy & 29 month & Pregabalin & $\begin{array}{l}\text { Reduced levels of consciousness, } \\
\text { seizures }\end{array}$ \\
\hline$[18]$ & $9.2 \mathrm{~g}$ & Bipolar disorder & 23 year & Citalopram, chlorpheniramine & $\begin{array}{l}\text { Reduced levels of consciousness, } \\
\text { ECG abnormalities }\end{array}$ \\
\hline [8] & $4.5 \mathrm{~g}$ & Epilepsy & 32 year & Ethanol, clonazepam & Ataxia, rotary nystagmus \\
\hline$[22]$ & $2 \mathrm{~g}$ & Epilepsy & 17 year & Gabapentin & $\begin{array}{l}\text { Reduced levels of consciousness, } \\
\text { dysarthria, motor incoordina- } \\
\text { tion }\end{array}$ \\
\hline [9] & 600 mg & Epilepsy & 31 year & Topiramate, carbamazepine & Nystagmus \\
\hline$[11]$ & $39 \mathrm{mg} / \mathrm{L}$ & Epilepsy, depression & 21 year & $\begin{array}{l}\text { Ethanol, thioridazine, } \\
\text { carbamazepine, paroxetine }\end{array}$ & Death \\
\hline$[20]$ & Unknown & Bipolar disorder & 29 year & Ethanol & $\begin{array}{l}\text { Coma, seizures, } \\
\text { mild rhabdomyolysis }\end{array}$ \\
\hline$[21]$ & Unknown & Epilepsy & 55 year & Valproic & Stupor \\
\hline$[6]$ & $7.5 \mathrm{~g}$ & & 48 year & - & $\begin{array}{l}\text { Status epilepticus, } \\
\text { cardiovascular collapse }\end{array}$ \\
\hline \multicolumn{6}{|l|}{ [7] } \\
\hline$[12]$ & $4 \mathrm{~g}$ & Bipolar disorder & 19 year & - & $\begin{array}{l}\text { Seizures, respiratory arrest, } \\
\text { complete heart block, death }\end{array}$ \\
\hline [23] & $4 \mathrm{~g}$ & Bipolar disorder, ADHD & 17 year & Bupropion & Seizures, cardiovascular collapse \\
\hline
\end{tabular}

its use. On the contrary, lamotrigine, when it is titrated slowly to avoid Stevens Johnson syndrome, seems to be a drug without any serious adverse effects. It is noteworthy that lamotrigine has been found to be one of the safest antiepileptic drugs in pregnancy [28].

\section{Conclusions}

In conclusion, mild rhabdomyolysis seems to be a primary effect of lamotrigine overdose, and lamotrigine appears to be quite safe in the case of overdose, especially when it is not combined with other medications.

\section{Consent}

Written informed consent was obtained from the patient for publication of this case report.

\section{Authors' contributions}

SEK wrote the manuscript, MS conceived the idea of presenting the case report and drafted the manuscript, and KF reviewed the final version of the manuscript. All authors read and approved the final manuscript.

\section{Acknowledgements}

The authors are grateful to the Professor of Medicine, Michael Sion, who gave us information about the patient during her stay at the Medical Clinic.

\section{Competing interests}

The authors declare that they have no competing interests.

Received: 21 May 2015 Accepted: 15 January 2016

Published online: 24 February 2016

\section{References}

1. Wade JF, Dang CV, Nelson L, Wasserberger J. Emergent complications of the newer anticonvulsants. J Emerg Med. 2010;38(2):231-7.

2. Fleurat M, Smollin C. Case files of the University of California San Francisco medical toxicology fellowship: lamotrigine toxicity. J Med Toxicol. 2012;8:52-8.

3. Lofton AL, Klein-Schwartz W. Evaluation of lamotrigine toxicity reported to poison centers. Ann Pharmacother. 2004;38(11):1811-5.

4. Kicka M, Klopotowski T, Picheta S, Bazylewicz A, Miskiewicz K. Massive lamotrigine poisoning-case report. Przeql Lek. 2011;68(8):543-5.

5. Buckley NA, Whyte IM, Dawson AH. Self-poisoning with lamotrigine. Lancet. 1993:33:557-9.

6. Nogar JN, Minns AB, Savaser DJ, Ly BT. Severe sodium channel blockade and cardiovascular collapse due to a massive lamotrigine overdose. Clin Toxicol (Phila). 2011;49(9):854-7.

7. Waring WS. Lamotrigine overdose associated with generalized seizures. BMJ Case Rep http://dx.doi.org/10.1136\%2Fbcr.07.2008.0489.

8. O'Donnell J, Bateman DN. Lamotrigine overdose in an adult. J Toxicol Clin Toxicol 2000;38(6):659-60. 
9. Oh Sum-Young, JS Kim, YH Lee, AY Lee, J Kim, JM Kim. Downbeat, position and perverted head-shaking nystagmus associated with lamotrigine toxicity. J Clin Neurology 2006;2:283-5.

10. Moore PW, Donovan JW, Burkhart KK, Haggerty D. A case series of patients with lamotrigine toxicity at one center from 2003 to 2012. Clin Toxicol (Phila). 2013;51(7):545-9.

11. Pricone MG, King CV, Drummer OH, Opeskin K, Mclntyre IM. Postmortem investigation of lamotrigine concentrations. J Forensic Sci. 2000;45:11-5.

12. French LK, McKeown NJ, Hendrickson RG. Complete heart block and death following lamotrigine overdose. Clin Toxicol (Phila). 2011;49(4):330-3.

13. Close BR, Banks CJ. Seizures secondary to lamotrigine toxicity in a twoyear old. Ann Pharmacother. 2010;44(6):1112-5.

14. Thundiyil JG, Anderson IB, Stewart PJ, Olson KR. Lamotrigine-induced seizures in a child: case report and literature review. Clin Toxicol. 2007;45:169-72.

15. Briassoulis G, Kalabalikis P, Tamiolaki M, Hatzis T. Lamotrigine childhood overdose. Pediatr Neurol. 1998;19:239-42.

16. Dinnerstein $E$, Jobst PC, Williamson PD. Lamotrigine intoxication provok ing status epilepticus in an adult with localization-related epilepsy. Arch Neurol. 2007;64(9):1344-6.

17. Braga AJ, Chidley K. Self-poisoning with lamotrigine and pregabalin. Anaesthesia. 2007;62:524-7.

18. Venkatraman N, O'Neil D, Hall AP. Life-threatening overdose with lamotrigine, citalopram and chlorpheniramine. J Postgrad Med. 2008;54(4):316-7.

19. Mylonakis E, Vittorio CC, Hollik DA, Round S. Lamotrigine overdose presenting as an anticonvulsant hypersensitivity syndrome. Ann Pharmacother. 1999;33(5):557-9.
20. Schwartz MD, Geller RJ. Seizures and altered mental status after lamotrigine overdose. Ther Drug Monit. 2007;29:843-4.

21. Sbei M, Campellone JV. Stupor from lamotrigine toxicity. Epilepsia. 2001;42(8):1082-3.

22. Stopforth J. Overdose with gabapentin and lamotrigine. S Afr Med J. 1997:87:1388.

23. Sirianni AJ, Osterhoudt KC, Calello DP, Muller AA, Waterhouse MR, Goodkin MB, Weinberg GL, Henretig FM. Use of lipid emulsion in the resuscitation of a patient with prolonged cardiovascular collapse after overdose of bupropion and lamoptrigine. Ann Emerg Med. 2008;51:412-5.

24. Nixon AC, Doak MW, Crozier H, Crooks DP, Waring WS. Patterns of antiepileptic drug overdose differ between men and women: admissions to the Edinburgh Poisons Unit, 2000-2007. Q J Med. 2009;102:51-5.

25. Dlamini N, Voermans NC, Lillis S, Stewart K, Kamsteeg EJ, Drost G, et al. Mutations in RYR1 are a common cause of exertional myalgia and rhabdomyolysis. Neuromuscul Disord. 2013;23(7):540-8.

26. Molenaar JP, Voermans NC, van Hoeve BJ, Kamsteeg EJ, Kluijtmans $L A$, Kusters B, et al. Fever-induced recurrent rhabdomyolysis due to a novel mutation in the ryanodine receptor type 1 gene. Intern Med J. 2014;44(8):819-20.

27. Scalco RS, Gardiner AR, Pitcheathly RD, Zanoteli E, Becker J, Holton $J$, et al. Rhabdomyolysis: a genetic perspective. Orphanet J Rare Dis. 2015;10(1):51. doi:10.1186/s13023-015-0264-3.

28. Berwaerts K, Sienaert P, De Fruyt J. Teratogenic effects of lamotrigine in women with bipolar disorder. Tijdschr Psychiatr. 2009;51(10):741-50.

\section{Submit your next manuscript to BioMed Central and we will help you at every step:}

- We accept pre-submission inquiries

- Our selector tool helps you to find the most relevant journal

- We provide round the clock customer support

- Convenient online submission

- Thorough peer review

- Inclusion in PubMed and all major indexing services

- Maximum visibility for your research

Submit your manuscript at www.biomedcentral.com/submit

() Biomed Central 